In seeking a diluent, one turns naturally first to metallic carbides other than calcium, with the idea of finding a commercially possible carbide which will give methane or hydrogen on decomposition with water and could be blended with calcium carbide by the manufacturer to suit, if necessary, various requirements, when we should once more see the early attempts to use for lighting the ordinary household Bray burner repeated with success. Manganese carbide is stated to be easily formed, and by Moissan to be decomposed by water yielding equal volumes of methane and hydrogen, hausmanite (presumably prepared by heating pyrolusite) being recommended. An attempt on my part to make a few grams, though it is true that the amperes at disposal only just reached double figures, failed as regards any gas produced, although reduction undoubtedly took place. I should not presume to quote so insignificant an experiment had not the manager of the Acetylene Illuminating Co., who courteously gave me an interview some months ago, told me that the Company's experiments on this carbide (and science is indebted to the Company for a great many researches, which I hope it may see fit to publish) had not led to the production of a carbide at all easily decomposed by water. I suggested the use of manganese mud as being easily obtainable, very free from silica as compared with pyrolusite, not so highly oxidised, and in a very fine state of division, and I hope that the Company may see fit to try it. Among other carbides, that of aluminium seems to offer attractions for commercial investigation, and although magnesium carbide cannot be prepared in the electric furnace alone, I do not think that dolomite as a substitute for pure carbonate of lime has been experimented upon.

Failing a suitable carbide for dilution, will not some organic chemist come forward with a bye-or waste product which will decompose in the presence of hot caustic lime produced in the generator, with, if not the production of methane, hydrogen or carbon monoxide, at least some indifferent gas, such as nitrogen or carbon dioxide?

Investigations are wanted as to the amount of diluent required to banish luminosity under some standard conditions. I can only speak at present of carbon dioxide ; a Bunsen burner consuming one cubic foot of acetylene per hour under six inches water pressure, showing a fully developed luminous zone rather greater in diameter than the sum of the widths of the nonluminous zone on either side, requires a supply of carbon dioxide at the rate of $Q^{+} I 5$ cubic feet per hour to destroy completely this luminosity.

A. E. Munby.

Felsted, November 1 .

\section{Magnetic Iron Ore as a Material for Concrete Blocks}

THE account of harbour works in NATURE of October 24 (p. 639) causes me once more to draw attention to the great advantage which would be gained by the use of magnetic iron ore as a material for concrete blocks. If magnetite is used instead of ordinary rock in the shape of fragments, and magnetic sand or ilmenite sand instead of common sea sand, concrete blocks can be obtained which have all the strength of the ordinary concrete blocks and which weigh, when immersed in water, exactly twice as much as the ordinary blocks. Such an increase in weight makes the magnetic blocks far superior as regards resistance to the waves. Work constructed with mag. netic blocks will stand when other work will be destroyed. This superior effect of magnetic blocks is quite independent of the size of the blocks. The artifici $t$ increase of the size of ordinary concrete blocks is mentioned as a means of increasing the power of resistance, but there are certain to be some objections to this method, and if the great masses are ruptured after the rusting away of the cases, portions may give way. It is therefore better and more convenient to use the superior composition. As regards the expense, it may be mentioned that to obtain a good effect it is only necessary to use magnetic blocks for the most exposed spots of a dam, and more in the nature of a surface coating. There are immense natural deposits of magnetite, also of titanium ore, which latter is not of value for steel making, and it would surely be possible to obtain the necessary quantities in Scandinavia, or if for harbours in the East, then there would be inexhaustible supplies in southern India not too far from the coast. It has been argued that the iron ore would decay on exposure to sea water and that it would injure the cement. This may be true for inferior iron ores, but not for rich, pure magnetite and ilmenite, as I have proved by direct experiments. I have exposed fragments of magnetite to the action of filtered sea water in clean glass jars where every trace of decomposition would have been detected, but though I continued the test for a year the specimens stood the test very well. Moreover, I made sample blocks with Portland cement and subjected them to crushing tests, which showed them to be perfectly satisfactory as regards strength.

H. WARTH.

\section{The San Clemente Island Goat.}

LAST summer, at San Pedro, California, I was shown a goat which had just been brought over from San Clemente Island. Mr. Miiller, the owner of the animal, told me that the goats of that island, running practically wild since the unknown date of their introduction, were all alike, constituting an easily recognisable race. The animal was quite reddish, about the colour of a red deer; front of face black; a pale (reddish) stripe down each side of nose, and enclosing the eye ; cheeks black; chin light; ears blackish above; neck and anterior part of body strongly suffused with black. The light facial stripes were par. ticularly distinct.

The Santa Catalina Island goats, I was informed, are variously coloured. This is doubtless due to the fact that Catalina is a popular resort, and fresh animals are frequently introduced.

T. D. A. COCKERELL.

East Las Vegas, New Mexico, U.S.A., October 27.

\section{Food of Grass Snakes.}

MAY 1 say, in defence of Dr. Gerald Leighton (see p. 625), that on two occasions I have found mice inside grass snakes. The first case was on a moor near Parkstone, Dorset, where on opening a smallish snake we found a mouse only partly digested. The other case occurred here last year, when I found a small shrew in a large grass snake. Also with regard to them swallowing birds, I have three times found birds inside them. In each case they were young ones; two were probably young larks (they were both in one snake), and the other was a young robin.

Wellington College, Berks, October 28 .

C. M. ROGERS.

\section{THE OBSERVATORY OF MONT BLANC.'}

$\mathrm{I}$ observing the physical features of the Alpine regions, M. Vallot and the several members of his family show a devotion that no discouraging circum stances can damp, and an energy that rises superior to the inclemencies of the weather and the loneliness of the situation. His original observatory, constructed after much labour and in spite of many difficulties, was found to be in an unfortunate position, owing to the accumulation of snow with which neither labour nor expense could efficiently deal. Without hesitation this construction is abandoned, and in the light of greater experience a fresh site is selected and a new observatory built, where, from the peculiarity of configuration, snow cannot collect and interfere with the progress of the work. This building, constructed in 1898 , admirably fulfils its purpose, and here, at an altitude of $4358 \mathrm{~m}$., among the eternal snows, M. Vallot and his band of energetic lábourers pursue their scientific avocations. These are sufficiently various, and in the present volumes we have the result of three distinct investigations, one dealing with the influence of barometric pressure on the chemical action of solar light, another on the velocity of water in streams and under glaciers, while the last gives an account of experiments undertaken with the view of detecting the rate and character of glacier motion.

Of the first of these discussions it is sufficient to say that the author aims at a re-examination of the adequacy of the formula found by Bunsen and Roscoe in similar researches, wherein occurs a numerical coefficient

1 "Annales de l'Observatoire météorologique physique et glaciaire du Mont Blanc." Publiées sous la direction de J. Vallot, Fondateur et Directeur de l'Observatoire. Tome iv. Pp. ix +189. Tome v. Planches du Tome iv. (Paris: G. Steinheil, Editeur, rgos.) NO. I672, VOL. 65$]$ 